\title{
Occupational stressors and irrational beliefs as predictors of teachers' mental health during the COVID-19 emergency state
}

\author{
Stanislava Popov ${ }^{1}$ \\ Faculty of Sport and Tourism, Educons University, Serbia \\ Jelena Sokić \\ Faculty of Sport and Tourism, Educons University, Serbia \\ Jelena Antić \\ Elementary school "Aleksa Šantić" Belgrade, Serbia
}

Education worldwide has been strongly affected by the COVID-19 pandemic. Given the previous evidence that teachers' wellbeing is under a tremendous negative influence of major societal disruptions, this kind of sudden overturn of the routines and practices that were in place for decades could have detrimental effects on teachers' mental health. In the present study, we are interested in examining specific occupational stressors and irrational cognitions as potential contributors to distress, depression, and anxiety among teachers, following enormous lockdown-induced changes in the educational system. The basic theoretical framework in the research is Rational-Emotive and Cognitive-Behavioural Therapy (RE \& CBT), according to which irrational beliefs have a critical contribution in generating and maintaining dysfunctional emotional reactions. Data were collected from 104 primary school teachers ( $88 \%$ female, age $M=41.39, S D=9.10)$ during the first wave of COVID-19, from the beginning of lockdown in March until its end in May 2020. We administered the adapted version of the Sources of stress at work questionnaire (IRS), the Teacher Irrational Beliefs Scale (TIBS) and the Depression, Anxiety and Stress Scale (DASS21). The questionnaires were distributed electronically by professional associates in schools since classes were conducted online at the time. The results of the hierarchical regression analysis suggest that, when it comes to experiencing stress due to changes in working and living conditions, both the COVID-19 related sources of stress $(\beta=.32, \mathrm{p}<.005)$ and irrational cognitions $(\beta=.25, \mathrm{p}<.01)$ have an independent and significant contribution. However, irrational cognitions only play a significant role in experiencing anxiety $(\beta=.33, \mathrm{p}<.005)$ and depression $(\beta=.36, \mathrm{p}<.005)$.

1 stanislava.popov@tims.edu.rs 
Keywords: occupational stressors, irrational beliefs, teachers' mental health, COVID-19

\section{Introduction}

\section{Occupational stress among teachers}

We talk about work-related or occupational stress when employees face job demands which exceed their professional knowledge and skills and available resources to overcome emerging conditions (Leka et al., 2003). Work-related stress is, therefore, a response to unfavourable working conditions that are perceived as stressors. A wide range of disadvantages can be included in the conditions for the occurrence of stressors. They can be classified into those that arise from the characteristics of the workplace, the role in the organization and interpersonal relations, conditions for professional advancement, etc. (Cousins et al., 2004). These stress sources can be observed in different professions, considered within one specific profession or compared in different professions. In such research, the emphasis is often placed on "helping" the professions that are considered particularly stressful, for example, health and educational workers. As a specific form of stress at work, teachers' stress has frequently been studied in regular professional circumstances to reveal situational and personal factors that contribute to stress-related psychological states of employees in education. According to a research study conducted in different countries worldwide, teachers perceive their profession as very stressful compared to many other professions (Jepson \& Forrest, 2006). Increased interest in teacher stress research has been driven by the fact that prolonged stress at work contributes to mental and physical health issues (e.g. depression), as well as by increased concern for teachers' quality of life and work, and the acknowledgement that stress can negatively affect the quality of teaching and the relationship between teachers and students (BermejoToro \& Prieto-Ursua, 2006). Most research results indicate that about 30\% of teachers in Serbia perceive the profession as very stressful (Krnjajić, 2003), and several international studies have shown that 60 to $70 \%$ of teachers repeatedly manifest symptoms of stress (Bermejo-Toro \& Prieto-Ursua, 2006).

What is specific about the teaching profession that makes this job especially stressful? A meta-analysis that dealt with teachers' stress stated that the primary sources of teachers' stress were the lack of motivation and discipline in students, significant and frequent changes in the educational system, evaluation of their work, workload and time pressures, conflicts with administration and lack of school equipment (Kyriacou, 2001). Other studies show that teachers find their job demanding but poorly paid and disrespected by the society (Jarvis, 2002; Jepson \& Forrest, 2006) and deem it challenging to reconcile private and professional roles (Suzić \& Graonić, 2009). Some significant sources of stress include lack of support from colleagues and 
difficult communication with the parents of the students (Prakke et al., 2007; Živčić-Bećirević \& Smojver-Ažić, 2005). The perception of the circumstances in which teaching is performed and the degree of control that the teacher has over these circumstances are mentioned in all teacher stress definitions (Krnjajić, 2003). Research on teacher stress in Serbia before the COVID-19 pandemic indicates that about $24 \%$ of teachers report significantly high anxiety, about $19 \%$ report significant stress at work, and about $15 \%$ report depression associated with the sources of stress at work (Popov et al., 2015).

Sources of stress alone are not sufficient to create the experience of stress. In the first place, different sources of stress will have a different effect on each teacher concerning the complex interaction with his/her characteristics and specific circumstances (Montgomery \& Rupp, 2005). To explain occupational stress in the "helping" professions, cognitive models that emphasize the role of cognitive factors in mediation between stressors and stress response are mainly considered (Van Dick \& Wagner, 2001). The central aspect of the cognitive approach in explaining stress is that people react to an internal representation or interpretation of the situation, not to objective situational features (Lehrer et al., 2007).

\section{Teacher stress in a cognitive-behavioural perspective}

Cognitive-behavioural therapies are behavioural correction techniques combined with cognitive therapy techniques (Hazlett-Stevens \& Craske, 2002). Rational-emotional and cognitive behavioural therapy (RE \& CBT), in line with other cognitive approaches in explaining stress, also holds that emotional reaction is not a direct consequence of the stressor. Instead, an emotional response is mediated by individual attitudes and beliefs about this stressor (Ellis, 1994). Specific to the RE \& CBT is the difference between rational/irrational beliefs that people may have about stressful situations. Depending on whether people hold onto their rational or irrational beliefs in stressful situations, they will develop a "healthy" or "unhealthy" emotional response (Popov et al., 2015).

Irrational beliefs are extreme, rigid and inconsistent with reality and prevent a person from achieving his/her life goals (David et al., 2005). Therefore, irrational beliefs represent cognitive vulnerability for developing various emotional problems and distress (David et al., 2005). RE \& CBT recognizes four types of irrational beliefs: demands, awfulizing beliefs, low frustration tolerance, and self/other/life depreciation beliefs (Dryden, 2002). Concerning the above general groups of irrational beliefs, Bernard and Joyce (1984) list 16 irrational beliefs specific to teachers. One illustrative example of such a belief is "I must have complete control of the class at all times" (this claim would belong to the group of absolutistic demands). Such beliefs participate in developing and maintaining an unhealthy emotional response 
that discourages people from changing what they can change or from constructively adapting to those situations that they cannot change (Dryden, 2002). Challenging irrational beliefs is a crucial component of the RE \& CBT practice (Ellis \& Dryden, 2007).

RE \& CBT has long been used to explain work stress, but mainly through research into the effectiveness of these programmes on reducing employee stress (e.g. Gardner et al., 2005; van der Klink et al., 2001). Few studies have examined the RE \& CBT diathesis-stress model, i.e. the interaction between work stressors and specific irrational beliefs in predicting occupational stress (e.g. Popov \& Popov, 2013). Several studies have dealt with teacher stress in the context of RE \& BT. In addition to the psychometric operationalization of the questionnaires that examine teachers' irrational beliefs and the correlation between cognitive factors and emotional disturbance, they address the moderating/mediating role of irrational beliefs in work-related stress in teachers (e.g. Bernard, 2016; Bermejo-Toro \& Prieto-Ursua, 2006, 2006; Popov et al., 2015). The study results unequivocally indicate the connection of irrational beliefs of teachers with different forms of distress (Bermejo-Toro \& Prieto-Ursua, 2006). More irrational beliefs in teachers are reflected in their lower efficacy compared to the teachers with a lower degree of irrational beliefs (Terjesen \& Kurasaki, 2009). Studies on the sources and consequences of stress at work conducted in Serbia before the COVID-19 pandemic show that irrational beliefs, even when the sources of stress are kept under statistical control, significantly contribute to psychological distress of respondents (Popov \& Popov, 2013).

\section{Teacher stress during the COVID-19 pandemic}

The subject of this research is teachers' stress and the related emotional changes provoked by specific situational and personal cognitive factors during a state of emergency imposed due to the COVID-19 pandemic. The COVID-19 pandemic, in addition to being a severe threat to physical health, has provoked significant changes in the organization of people's lives, as well as global social changes in various segments, especially in terms of the transition to online work from home. Many studies have been published on the psychological consequences of the COVID-19 pandemic in its various phases. Studies conducted at the time of social distancing and lockdown in different countries indicated an increased degree of depressed mood, sleeping problems, and even the symptoms of post-traumatic stress (e.g. Pfeferbaum \& North, 2020). The measures of social distance and lockdown inevitably contributed to an enhanced experience of isolation and loneliness in humans (Smith \& Lim, 2020). Particularly significant consequences were suffered 
by those exposed to sudden and large changes in the economic, social and family context (Guo et al., 2020).

The COVID-19 pandemic has significantly affected education around the world. Schools were mainly closed due to social distancing measures, and, wherever there were opportunities, they switched to online teaching. These changes led to new sources of stress at work for teachers and the activation of specific irrational beliefs related to their professional status and work. The adverse effects of new sources of stress at work during the COVID-19 pandemic on teachers' mental health have already been attested in various studies (e.g. Ozamiz-Etxebarria et al., 2021). The most significant stressor was the demand for rapid adaptation to online teaching (Besser et al., 2020). UNESCO (2020a) states that teachers' stress is primarily due to the closure of schools, non-familiarity with distance learning, and the uncertain duration of these measures introduced to prevent the spread of the pandemic. However, the impact of irrational beliefs from the RE \& CBT perspective is currently unexplored.

This research aims to explore the role of irrational beliefs and COVID-19 related sources of stress in the levels of acutely experienced symptoms of stress, anxiety and depression during the first wave of the COVID-19 pandemic. In addition to information on teachers' emotional stress response to the newly created working conditions in an emergency, we are also interested in validating the RE \& CBT diathesis-stress model in the context of teaching in an emergency. We hypothesize an independent contribution of COVID-19 related sources of stress and irrational beliefs on anxiety, depression and stress, and the moderating effect of irrational beliefs in the relationship between stressors and teachers' psychological distress.

\section{Method}

\section{Participants}

A convenient sample was used in this research. It consisted of 104 primary school teachers (85\% female) from Belgrade and the vicinity of Belgrade (age range 25-62, $M=41.39, S D=9.10)$. Work experience of the respondents ranged from 1 to 37 years $(M=13.79, S D=10.25)$.

\section{Procedure}

Data collection was performed during the state of emergency in Serbia, declared due to the COVID-19 pandemic (March 15, 2020 to May 6, 2020). Distance learning classes began in all primary and secondary schools in the Republic's territory, starting from March 16. School psychologists were approached through the professional association of school psychologists. The 
school psychologists who accepted cooperation forwarded the questionnaires to teachers in their schools via e-mail. Given that the e-mail addresses were known to the school psychologists who collected the data, we cannot say that the anonymity of the respondents was completely ensured. On the other hand, as for the authors of the study, the data were received anonymously.

The questionnaires were distributed to teachers after the second week of school closure. The questionnaires were sent with all the necessary instructions for completion. Participation was voluntary, and participants were introduced to the research subject and informed that all the data would be processed collectively and used exclusively for scientific purposes. The respondent had the opportunity to withdraw by not sending the completed questionnaire to the examiner.

\section{Instruments}

1. An adapted questionnaire of the Sources of stress at work (Popov \& Popov, 2013) was used to estimate the frequency of stressors related to work in school during the COVID-19 induced state of emergency in Serbia. The original questionnaire was adapted exclusively for this research by omitting some items (e.g. "There is an excellent working atmosphere among colleagues at work"), adjusting others (all items were formulated in a negative direction so that they represented adverse conditions), and supplementing them with new items which referred to the specifics of teaching and changes in work conditions during a state of emergency (e.g. online teaching, public exposure of teaching activity). The implemented questionnaire contained 36 items (e.g. "It happens to you that you cannot reconcile the role of a parent or private responsibilities and the role of the teacher."; "You do not influence what exactly your tasks will be."; "You lack the knowledge or skills for distance learning."). Although the total score of the scale was used in further analysis, the included stressors can generally be grouped around several topics: lack of skills and professional support, public exposure of teaching activities, students' and parents' behaviour, school administration demands. The answering format was a five-point Likert scale, represented by answers from (1) "almost never" to (5) "almost always".

2. The Depression, Anxiety and Stress Scale (DASS-21: Lovibond \& Lovibond, 1995) is a 21-item scale that consists of three subscales: (1) the Depression subscale, which is related to the level of experienced dysphoria, helplessness, anhedonia, inertia and low self-esteem (e.g. "I felt that I had nothing to look forward to."); (2) the Anxiety subscale, which measures the level of physiological arousal, somatic reactions, as well as the subjective experience of situational anxiety (e.g. "I felt 
scared without any good reason."); and (3) the Stress subscale, which assesses the level of chronic, non-specific arousal, a person's inability to relax, nervousness, impatience, a tendency for a person to be easily upset, agitated, irritated, and prone to overreact (e.g. "I tended to over-react to situations."). The answer format is a four-point Likerttype scale (from (0) "not at all" to (3) "mostly, almost always"). In this study, the Serbian translation of the instrument was used" The instructions were modified so that teachers assessed how they felt in the last two weeks due to work circumstances in the COVID-19 state of emergency.

3. The Teacher Irrational Beliefs Scale (TIBS: Bora et al., 2009) examined teachers' irrational beliefs. The questionnaire consists of 22 items which refer to four groups of irrational beliefs according to RE \& CBT: absolutistic demands, low frustration, tolerance and awfulizing and global evaluation, applied in the following areas of the teaching profession: competence, classroom management, work overload and problems with school administration. The scale includes four subscales: Demand for justice (e.g. "Without good teacher-administrator communication and support, schools are the very worst and terrible places to work."); Authoritarianism (e.g. "As a teacher, I should have the power to be to be able to make my students do what I want."); Low frustration tolerance (e.g. "I should not have to work so hard."); and Self-downing (e.g. "I think I am a failure when I have not 'got through' to a student or class."). The answering format was a five-point Likert scale, ranging from (1) "I strongly disagree" to (5) "I strongly agree". The translation of the scale into Serbian conducted by Popov et al., 2015 was used in this study.

\section{Data analysis}

Data were analysed in the statistical package IBM SPSS version 21, using descriptive statistics to describe and summarize the sample and dataset characteristics. Hierarchical regression analysis was used to explore the relationships between anxiety, depression and stress, on the one hand, and the COVID-related sources of stress and irrational beliefs, on the other.

\section{Results}

Table 1 shows the descriptive indicators for the variables used in the study: the total score on the Occupational stressors questionnaire and the

1 The scale in Serbian is available at the official website of the University of New South Wales: http://www2.psy.unsw.edu.au/dass/translations.htm. 
scores on the TIBS and DASS-21 subscales. We can see that skewness and kurtosis values for most of the variables are in a range that indicates a normal distribution, except for anxiety and depression, which slightly and expectedly deviate from normal. The value of Cronbach's alpha coefficient for each scale is satisfactory.

Table 1

Descriptive statistics for variables in the study

\begin{tabular}{lcccccc}
\hline Variables & $\begin{array}{c}\text { Achieved range } \\
\text { (Theoretical range) }\end{array}$ & $M$ & SD & Skewness & Kurtosis & $\alpha$ \\
\hline Stressors & $\begin{array}{c}48-126 \\
(36-180)\end{array}$ & 79.90 & 17.36 & .20 & -.25 & .90 \\
Self-downing (TIBS) & $\begin{array}{c}8-32 \\
(5-35)\end{array}$ & 17.42 & 5.64 & .37 & -.26 & .80 \\
LFT (TIBS) & $5-23$ & 12.11 & 4.62 & .50 & -.41 & .81 \\
Demand for Justice (TIBS) & $\begin{array}{c}5-25) \\
5-25\end{array}$ & 16.21 & 4.50 & -.26 & -.58 & .72 \\
Authoritarianism (TIBS) & $\begin{array}{c}(5-25) \\
5-24\end{array}$ & 14.80 & 4.56 & .04 & -.83 & .79 \\
Anxiety (DASS) & $\begin{array}{c}(5-25) \\
0-28\end{array}$ & 5.74 & 7.06 & 1.50 & 1.55 & .85 \\
Depression (DASS) & $\begin{array}{c}(0-42) \\
0-22\end{array}$ & 5.22 & 5.29 & 1.21 & 1.11 & .78 \\
Stress (DASS) & $\begin{array}{c}(0-42) \\
0-28\end{array}$ & 14.23 & 9.03 & .67 & .16 & .87 \\
\hline
\end{tabular}

Table 2 shows the cut-off values for the severity of anxiety, depression and stress symptoms recommended by the authors of the instrument (Lovibond \& Lovibond, 1995). The cut-off values on the abbreviated version of the scale used in this study (DASS-21) were calculated by doubling the results obtained on the three subscales, as the instrument's authors also recommended.

Table 2

Distribution of the DASS scores according to cut-off values

\begin{tabular}{lccccc}
\hline & \% Normal & \% Mild & \% Moderate & \% Severe & \% Extremely severe \\
\hline Anxiety & 69 & 8 & 11 & 3 & 9 \\
Depression & 79 & 11 & 8 & 2 & 0 \\
Stress & 62 & 11 & 13 & 10 & 4 \\
\hline
\end{tabular}

Note. ${ }^{\star}$ Lovibond \& Lovibond, 1995.

In Table 2, we can see that the highest percentage of results on all three subscales was within the scores that are considered normal. If we look at the results that exceed the normal range, and these results range from moderate to extremely severe, we can see that $23 \%$ of respondents experienced anxiety 
symptoms, $10 \%$ experienced symptoms of depression and $27 \%$ reported symptoms of stress.

In order to compare the obtained scores on the variables of teachers' mental health (anxiety, stress and depression) with the comparative sample of teachers (Popov et al., 2015) from a similar environment before the COVID-19 pandemic, we conducted a t-test for independent samples. The scores on all three mental health variables in this study did not differ statistically from the pre-COVID-19 time (depression $t(288)=1.36, p=.17$; anxiety $t(288)=$ $-.33, p=.74$; stress $t(288)=-.93, p=.35)$.

Table 3 shows the intercorrelations among the variables used in the study. We can see that the COVID-19 related occupational stressors are positively related to all irrational beliefs, except Demand for justice, and to Anxiety and Stress as mental health variables, but not to Depression. All groups of irrational beliefs are positively related to mental health variables except Authoritarianism, which positively correlates only with Anxiety.

Table 3

Intercorrelations between the variables

\begin{tabular}{llllllll}
\hline & 1 & 2 & 3 & 4 & 5 & 6 & 7 \\
\hline 1 Stressors & & & & & & & \\
2 Self-downing & $.24^{*}$ & & & & & & \\
3 Low Frustration Tolerance & $.48^{* *}$ & $.61^{* *}$ & & & & & \\
4 Demand for Justice & .19 & $.35^{* *}$ & $.53^{* *}$ & & & & \\
5 Authoritarianism & $.27^{*}$ & $.54^{* *}$ & $.46^{* *}$ & $.44^{* *}$ & & & \\
6 Anxiety & $.28^{*}$ & $.39^{* *}$ & $.43^{* *}$ & $.25^{* *}$ & $.22^{*}$ & & \\
7 Depression & .20 & $.39^{* *}$ & $.35^{* *}$ & $.36^{* *}$ & .18 & $.69^{* *}$ & \\
8 Stress & $.39^{* *}$ & $.25^{*}$ & $.44^{* *}$ & $.26^{* *}$ & .18 & $.76^{* *}$ & $.60^{* *}$ \\
\hline \multicolumn{7}{l}{ Note. ${ }^{*} p<.05,{ }^{* *} p<.01$. Stressors - Occupational stressors, LFT - Low Frustration Tolerance }
\end{tabular}

In order to measure the independent contribution of the sources of stress, irrational beliefs and their interaction with the level of the experienced teacher stress, as well as the symptoms of Anxiety and Depression, we conducted a hierarchical regression analysis. The results are shown in Table 4. The diathesis-stress model theoretically guided the order of predictor input. Sources of stress are general for all respondents because they were all exposed to them. On the other hand, irrational beliefs represent personal characteristics that are subject to change and are one of the aspects of a reaction that can impact subjective experience and expression of emotion.

The first set of predictor variables consisted of COVID-19 related sources of stress, the second set of predictors were irrational beliefs, and the third was the interaction between these variables. The model was statistically significant in the case of all three mental health indicators (Depression: $F=3.76 R^{2}=.04$, $p<.01$; Anxiety: $F=6.92 R^{2}=.08, p<.01$; Stress: $F=16.50 R^{2}=.17, p<.001$ ). The second set of predictor variables consisted of irrational beliefs and made the 


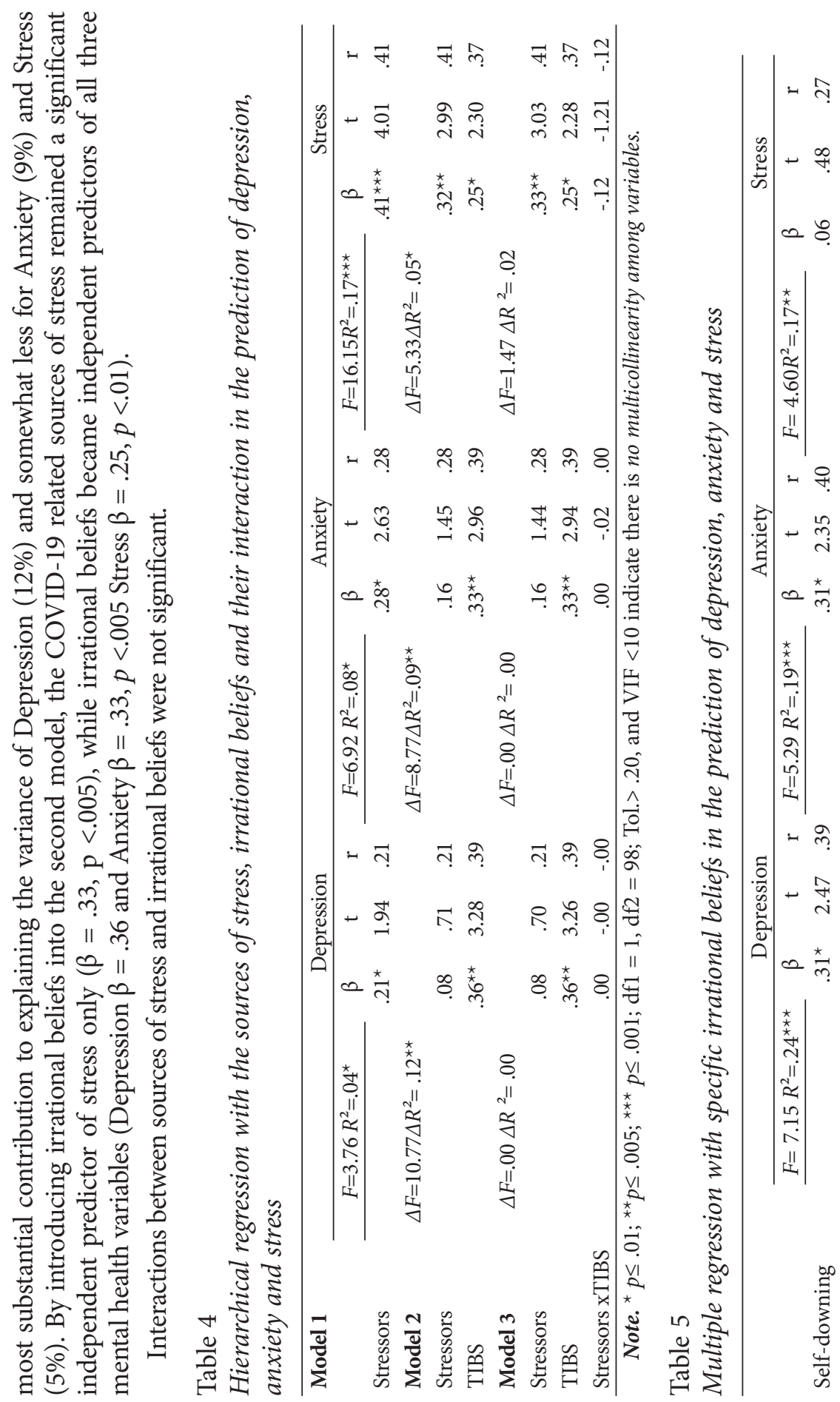


POPOV S., SOKIĆ J., ANTIĆ J.: OCCUPATIONAL STRESSORS AND IRRATIONAL BELIEFS

$\begin{array}{lcccccc}\text { Low Frustration } & .09 & .76 & .37 & .14 & 1.04 & .36 \\ \text { Tolerance } & & & & & & \\ \text { Demand for Justice } & .28^{*} & 2.54 & .38 & .11 & .94 & .26 \\ \text { Authoritarianism } & -.15 & -1.31 & .19 & -.06 & -.49 & .23\end{array}$

Note. ${ }^{*} p \leq .01 ;{ }^{* *} p \leq .005 ;{ }^{* *} p \leq .001 ; \mathrm{df} 1=1, \mathrm{df} 2=98$; Tol. $>.20$, and VIF $<10$ indicate there is no multicollinearity among variables.

Table 5 shows the results of a regression analysis in which we examined the contribution of individual groups of teachers' irrational beliefs to anxiety, depression, and the experience of stress. The findings suggest that different groups of irrational beliefs predict different mental health states. Self-downing $(\beta=.31, p<.01)$ was an important predictor of depression and anxiety, while the Demand for Justice $(\beta=.28, p<.01)$ was a significant predictor of depression. Low frustration tolerance $(\beta=.33, p<.005)$ was a significant predictor of stress reaction.

\section{Discussion}

The COVID-19 pandemic has undoubtedly affected education worldwide (UNESCO, 2020). Due to social distance measures in many countries, including Serbia, classes were conducted online. Many were sceptical about the quality of such teaching and wondered what impact it would have on the quality of the acquired knowledge among students. The key question was how the change in the usual routine affected the mental health of students and teachers. This research, therefore, addressed teacher stress and the related emotional changes caused by specific situational and personal cognitive factors during the 2020 state of emergency in Serbia caused by the COVID-19 pandemic. The main goal was to determine the specific relationships between the sources of teacher stress in extraordinary circumstances, irrational beliefs regarding their work role in the school, and the levels of acutely experienced stress, anxiety and depression. The theoretical framework of this research was the theory of RE \& CBT.

All the scales used in the study showed satisfactory internal consistency. Based on the descriptive analysis of the sample characteristics, it can be concluded that $27 \%$ of teachers experienced moderate to extreme symptoms of stress during the state of emergency. Anxiety symptoms were reported by $23 \%$ of teachers, while moderate to severe symptoms of depression were experienced by $10 \%$ of the examined teachers, according to the recommended cut-off values (Lovibond \& Lovibond, 1995). However, when we compare the average scores of teachers on mental health variables during the state of emergency in the COVID-19 pandemic with a comparative sample of teachers from Serbia before the pandemic (Popov et al., 2015), we see that the level of anxiety, depression, and stress was not significantly higher during 
the COVID-19 state of emergency. Nevertheless, it is important to emphasize that this does not mean that teachers have not reacted emotionally. In the context of RE \& CBT, events are not direct causes of emotional reactions but our specific interpretation of these events so that regardless of the specificity of the source of stress at work, an emotional reaction will depend more on the individual's beliefs (David et al., 2005). Given the percentage of pronounced symptoms of anxiety, depression and stress as a reaction to sources of stress at work in our environment, before (Popov et al., 2015) and during the first wave of the COVID-19 pandemic, teachers consistently perceive working conditions as stressful, so the change in working conditions during the first wave of pandemic did not provoke more intense reactions than usual. In this case, teacher beliefs seem to be a more critical factor than the stressors at work that contribute to psychological distress. The question is whether the results would remain in the other phases of the pandemic, given that working conditions have been changing with the (mal) adaptation of the entire society to the pandemic. Some studies suggest that teachers' anxiety, depression, and stress were not limited to the lockdown period but were also characteristic of the later stages of the pandemic (Ozamiz-Etxebarria et al., 2021). Also, switching to online teaching may have had more benefits for some teachers than potential harms or challenges (e.g. not being directly exposed to the virus as they would be in classrooms, working from home or other places, possible flexibility in working hours...), but this is a premise that should have been additionally investigated.

This research has explored the impact of specific sources of professional stress and work-related irrational beliefs on teachers' emotional distress during the state of emergency. We were interested in checking the RE \& CBT diathesis-stress model, i.e. the interaction between specific stressors at work and irrational beliefs in predicting occupational stress. With these intentions, a regression analysis was conducted, which showed that the sources of stress at work made a significant independent contribution to the prediction of stress, anxiety and depression until personal cognitive factors were introduced into the model, and then lost significance or decreased significantly. Only in the case of stress as a criterion variable, the sources of stress represented a stronger predictor than irrational beliefs. In predicting depression and anxiety, only irrational beliefs had a statistically significant contribution when they were introduced into the model. However, the interaction between stress sources and irrational beliefs was not significant, i.e. the RE \& CBT diathesisstress model was not confirmed in this study, which has already been the case in previous studies (e.g. Popov \& Popov, 2013). However, this does not diminish the interpretability of the results. For an experience of stress in a state of emergency, sources of stress are a stronger predictor because stress is in itself a "normal reaction to abnormal circumstances" (Pedrosa et al., 2020). However, in anxiety and depression, personal cognitive factors play a more 
significant role. REBT distinguishes between the emotions that may have an unpleasant tone, but healthy or unhealthy effects (Vukosavljević-Gvozden, 2009). In other words, it distinguishes between constructive and destructive unpleasant emotions. Anxiety and depression are feelings with "unhealthy" effects, and the irrational beliefs that people hold are considered essential factors in their emergence and maintenance. The difference between healthy and unhealthy unpleasant emotions follows from their connection with the (ir)rational beliefs. Healthy negative emotions stem from the rational and the unhealthy ones from irrational beliefs (Dryden, 2002). A meta-analysis dealing with the studies that examined the relationship between irrational beliefs and psychological distress showed that this relationship was modest, but stable across different samples, measurements and research designs (Vîslă et al., 2016).

According to the RE \& CBT theory, neither the irrational beliefs nor the instrument used to measure teachers' irrational beliefs are unidimensional constructs. Hence, we were interested in the way in which individual groups of beliefs contributed to the prediction of mental health. When it comes to the impact of the specific groups of teachers' irrational beliefs on the level of experienced stress, anxiety and depression, the results are also in line with theoretical expectations and previous research in the field (Oltean et al., 2017). Attitudes towards paperwork are also significant predictors of depression, while low frustration tolerance significantly predicts a stress response. When it comes to low frustration tolerance, the items that define this dimension refer to the experience of teacher workload, which, in the REBT language, indicates discomfort anxiety (Dryden, 2002). Consequently, the connection between LFT and general anxiety is theoretically expected. In many studies examining the relationship between specific irrational beliefs and emotional disturbance, self-downing explains the most variance in depression severity (e.g. Tecuta et al., 2019). However, attitudes towards paperwork in this study possibly predict depression because they are grouped around (irrational) beliefs that teachers hold about how school management should treat them, which, in a specific state of emergency, can further contribute to their experience of helplessness.

The main advantage of this research is the fact that it deals with teachers' mental health during the changed working conditions in the state of emergency in Serbia in 2020, caused by the COVID-19 pandemic. Given that the situation was extraordinary and that, in addition to the risk to physical and mental health, it significantly affected normal working conditions, this research offers valuable data on the teachers' response and the specific factors that influenced it. Furthermore, it is one of a few studies that examine the RE \& CBT diathesis-stress model in the context of teacher occupational stress. Besides the correlational design and self-assessment data, the study's main limitation is a relatively small and convenient sample that was available to the examiners. Overcoming these shortcomings is a recommendation for 
future research. It is also recommended to examine the protective role of rational beliefs in psychological resilience in stressful situations. Nevertheless, the results offer helpful information and guidance for school psychologists and school management to improve organizational and mental health and the work efficiency of teachers in extraordinary circumstances. Information about the relationship between specific irrational beliefs and mental health variables can help design preventive mental health programmes for teachers.

\section{References}

Aperribai, L., Cortabarría, L., Aguirre, T., \& Verche, E. (2020). Teacher’s Physical Activity and Mental Health During Lockdown Due to the Covid-2019 Pandemic. Frontiers in Psychology, 11, 2673. https://doi.org/10.3389/fpsyg.2020.577886

Bernard, M. E. (2016). Teacher Beliefs and Stress. Journal of Rational-Emotive \& Cognitive-Behavior Therapy, 34, 209-224. https://doi.org/10.1007/s10942-016-0238-y

Bernard, M. E., \& Joyce, M. R. (1984). Rational-emotive therapy with children and adolescents. Wiley.

Bermejo-Toro, L., \& Prieto-Ursúa, M. (2006). Teachers' irrational beliefs and their relationship to distress in the profession. Psychology in Spain, 10, 88-96.

Besser, A., Lotem, S., \& Zeigler-Hill, V. (2020). Psychological Stress and Vocal Symptoms Among University Professors in Israel: Implications of the Shift to Online Synchronous Teaching During the COVID-19 Pandemic. Journal of voice, S0892-1997(20)30190-9. https://doi.org/10.1016/j.jvoice.2020.05.028

Bora, C., Bernard, M. E., \& Decsei-Radu, A. (2008). Teacher irrational belief scalePreliminary norms for Romanian population. Romanian Journal of Cognitive and Behavioral Psychotherapies, 8, 35-49.

Cousins, R., MacKay, C. J., Clarke, S. D., Kelly, C., Kelly, P. J., \& McCaig, R. H. (2004). Management standards and work-related stress in the UK: Practical development. Work \& Stress, 18, 113-136. https://doi.org/10.1080/02678370410001734322

David, D., Szentagotai, A., Eva, K., \& Macavei, B. (2005). A synopsis of rational-emotive behavior therapy (RE \& CBT); Fundamental and applied research. Journal of Rational-Emotive \& Cognitive-Behavior Therapy, 23, 175-221. https://doi. org/10.1007/s10942-005-0011-0

Dryden, D. W. (2002). Fundamentals of rational emotive behaviour therapy: A training handbook. Wiley.

Ellis, A. (1994). Reason and emotion in psychotherapy. Birch Line Press.

Ellis, A. E., \& Dryden, D. W. (2007). The practice of rational emotive behavior therapy: Second edition. Springer.

Gardner, B., Rose, J., Mason, O., Tyler, P., \& Cushway, D. (2005). Cognitive therapy and behavioural coping in the management of work-related stress: An intervention study. Work \& Stress, 19(2), 137-152. https://doi. org/10.1080/02678370500157346 
Guo, J., Feng, X. L., Wang, X. H., \& van IJzendoorn, M. H. (2020). Coping with COVID-19: Exposure to COVID-19 and Negative Impact on Livelihood Predict Elevated Mental Health Problems in Chinese Adults. International Journal of Environmental Research and Public Health, 17, 3857. https://doi.org/10.3390/ ijerph 17113857

Hazlett-Stevens, H., \& Craske, M.G. (2002). Brief cognitive-behavioral therapy: Definition and scientific foundations. In F.W. Bond \& W. Dryden (Eds.), Handbook of brief cognitive behavior therapy. Wiley. https://doi.org/10.1002/9780470713020.ch1

Jarvis, M. (2002). Teacher stress: A critical review of recent findings and suggestions for future research directions. Stress News, 14, 12-16.

Jepson, E., \& Forrest, S. (2006). Individual contributory factors in teacher stress: The role of achievement striving and occupational commitment. The British Journal of Educational Psychology, 76, 183-197. https://doi.org/10.1348/000709905x37299

Krnjajić, S. (2003). The teacher under stress. Zbornik Instituta za pedagoška istraživanja, 35, 222-244. https://doi.org/10.2298/zipi0335222k

Kyriacou, C. (2001). Teacher stress: Directions for future research. Educational Review, 53, 27-35. https://doi.org/10.1080/00131910120033628

Lehrer, P. P. M., Woolfolk, P. R. L., \& Sime, P. W. E. (2007). Principles and practice of stress management (3rd edition). Guilford Press.

Leka, S., Griffiths, A., \& Cox, T. (2003). Work organisation and stress. World Health Organization.

Lovibond, S. H. \& Lovibond, P. F. (1995). Manual for the Depression Anxiety \& Stress Scales (2nd Ed.). Psychology Foundation.

Montgomery, C., \& Rupp, A. A. (2005). A meta-analysis for exploring the diverse causes and effects of stress in teachers. Canadian Journal of Education/Revue canadienne de l'éducation, 28, 458. https://doi.org/10.2307/4126479

Oltean, H. R., Hyland, P., Vallières, F., \& David, D. O. (2017). An Empirical Assessment of REBT Models of Psychopathology and Psychological Health in the Prediction of Anxiety and Depression Symptoms. Behavioural and cognitive psychotherapy, 45(6), 600-615. https://doi.org/10.1017/S1352465817000133

Ozamiz-Etxebarria, N., Berasategi Santxo, N., Idoiaga Mondragon, N., \& Dosil Santamaría, M. (2021). The Psychological State of Teachers During the COVID-19 Crisis: The Challenge of Returning to Face-to-Face Teaching. Frontiers in psychology, 11, 620718. https://doi.org/10.3389/fpsyg.2020.620718

Pedrosa, A. L., Bitencourt, L., Fróes, A., Cazumbá, M., Campos, R., de Brito, S., Simões E., \& Silva, A. C. (2020). Emotional, Behavioral, and Psychological Impact of the COVID-19 Pandemic. Frontiers in psychology, 11, 566212. https:// doi.org/10.3389/fpsyg.2020.566212

Pfefferbaum, B., \& North, C. S. (2020). Mental Health and the Covid-19 Pandemic. The New England Journal of Medicine, 383, 510-512. https://doi.org/10.1056/ NEJMp2008017

Popov, B., \& Popov, S. (2013). Adverse working conditions, job insecurity and occupational stress: The role of (ir)rational beliefs. Journal of Rational-Emotive \& Cognitive-Behavior Therapy, 31(1), 27-38. https://doi.org/10.1007/s10942-012-0157-5 
Popov, S., Popov, B., \& Damjanović, R. (2015). The role of stressors at work and irrational beliefs in the prediction of teachers' stress. Primenjena psihologija, 8(1), 5-23. https://doi.org/10.19090/pp.2015.1.5-23

Prakke, B., van Peet, A., \& van der Wolf, K. (2007). Challenging parents, teacher occupational stress and health in Dutch primary schools. International Journal about Parents in Education, 1, 36-44.

Smith, B. J., \& Lim, M. H. (2020). How the COVID-19 pandemic is focusing attention on loneliness and social isolation. Public health research \& practice, 30(2), 3022008. https://doi.org/10.17061/phrp3022008

Suzić, N., \& Graonić, J. (2009). The syndrome of burning ambition in teaching profession. Pedagoška stvarnost, 55, 813-826.

Tecuta, L., Tomba, E., Lupetti, A., \& DiGiuseppe, R. (2019). Irrational beliefs, cognitive distortions, and depressive symptomatology in a college-age sample: A mediational analysis. Journal of Cognitive Psychotherapy, 33(2), 116-127. https:// doi.org/10.1891/0889-8391.33.2.116

Terjesen, M. D., \& Kurasaki, R. (2009). Rational emotive behavior therapy: Applications for working with parents and teachers. Estudos de Psicologia (Campinas), 26, 3-14. https://doi.org/10.1590/s0103-166x2009000100001

United Nations Educational, Scientific and Cultural Organization (UNESCO) (2020a). Adverse effects of school closures, 2020. UNESCO.

United Nations Educational, Scientific and Cultural Organization (UNESCO) (2020b). COVID-19 educational disruption and response. 2020. UNESCO.

van der Klink, J. J., Blonk, R. W., Schene, A. H., \& van Dijk, F. J. (2001). The benefits of interventions for work-related stress. American journal of public health, 91(2), 270-276. https://doi.org/10.2105/ajph.91.2.270

van Dick, R., \& Wagner, U. (2001). Stress and strain in teaching: A structural equation approach. British Journal of Educational Psychology, 71, 243-259. https:// doi.org/10.1348/000709901158505

Vîslă, A., Flückiger, C., grosse Holtforth, M., \& David, D. (2016). Irrational Beliefs and Psychological Distress: A Meta-Analysis. Psychotherapy and psychosomatics, 85(1), 8-15. https://doi.org/10.1159/000441231

Vukosavljević-Gvozden, T. (2009). Racionalno-emotivna bihejvioralna terapija: teorija i metod. Kreativni centar.

Živčić-Bećirević, I., i Smojver-Ažić, S. (2005). Origins of work stress in kindergarten teachers. Psihologijske teme, 14, 3-13. 


\section{Izvori profesionalnog stresa $\mathrm{i}$ iracionalna uverenja kao prediktori mentalnog zdravlja nastavnika tokom COVID-19 pandemije}

\section{Stanislava Popov ${ }^{2}$}

Fakultet za sport i turizam, Edukons Univerzitet, Srbija

\section{Jelena Sokić}

Fakultet za sport i turizam, Edukons Univerzitet, Srbija

\section{Jelena Antić}

Osnovna škola „Aleksa Šantič”, Beograd, Srbija

Obrazovanje širom sveta snažno je pogođeno COVID-19 pandemijom. S obzirom na ranije dokaze da je blagostanje nastavnika pod uticajem velikih društvenih promena, ova vrsta iznenadne promene rutine i prakse koje su postojale decenijama mogla bi imati štetne učinke na mentalno zdravlje nastavnika. U ovoj studiji težili smo da ispitamo doprinos specifičnih stresora na radnom mestu i iracionalnih uverenja objašnjenju doživljavaja stresa, depresije i anksioznosti među nastavnicima, nakon velikih promena u obrazovnom sistemu uzrokovanih vanrednom situacijom. Teorijski okvir istraživanja je Racionalno-emotivna i Kognitivno-bihejvioralna Terapija (RE i KBT), prema kojoj iracionalna uverenja imaju ključni doprinos u generisanju i održavanju disfunkcionalnih emocionalnih reakcija. Podaci su prikupljeni od 104 nastavnika osnovnih škola ( $88 \%$ žena, uzrasta $M=41,39, S D=9,10)$ tokom prvog talasa COVID-19 pandemije (mart do maja 2020.). Za prikupljanje podataka smo koristili prilagođenu verziju upitnika Izvori stresa na radu (IRS), Skalu iracionalnih uverenja nastavnika (TIBS) i Skalu depresije, anksioznosti i stresa (DASS-21). Upitnike su elektronskim putem distribuirali stručni suradnici u školama, budući da se u to vreme nastava odvijala "online". Rezultati hijerarhijske regresione analize sugerišu da, kada je reč o doživljavanju stresa zbog promena u radnim i životnim uslovima, izvori radnog stresa povezani s COVID-om $(\beta=, 32, p<, 005)$ i iracionalna uverenja $(\beta=, 25, p<, 01)$ imaju samostalan i značajan doprinos. Međutim, iracionalna uverenja predstavljaju jedine značajne prediktore $\mathrm{u}$ doživljavanju anksioznosti $(\beta$ $=, 33, p<, 005)$ i depresije $(\beta=, 36, p<, 005)$.

Ključne reči: stresori na radnom mestu, iracionalna uverenja, mentalno zdravlje nastavnika, COVID-19

2 stanislava.popov@tims.edu.rs 
